\title{
Paideusis
}

\section{A Philosopher's Journey from Hermeneutics to Emancipatory Politics}

\author{
Dieter Misgeld, Trevor Norris and Hossein Mesbahian
}

Volume 19, Number 2, 2010

URI: https://id.erudit.org/iderudit/1071925ar

DOI: https://doi.org/10.7202/1071925ar

See table of contents

Publisher(s)

Canadian Philosophy of Education Society

ISSN

0838-4517 (print)

1916-0348 (digital)

Explore this journal

Cite this document

Misgeld, D., Norris, T. \& Mesbahian, H. (2010). A Philosopher's Journey from Hermeneutics to Emancipatory Politics. Paideusis, 19(2), 86-97.

https://doi.org/10.7202/1071925ar

(c) Dieter Misgeld, Trevor Norris, Hossein Mesbahian, 2010

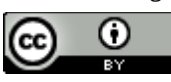

This document is protected by copyright law. Use of the services of Érudit (including reproduction) is subject to its terms and conditions, which can be viewed online.

https://apropos.erudit.org/en/users/policy-on-use/
This article is disseminated and preserved by Érudit.

Érudit is a non-profit inter-university consortium of the Université de Montréal, Université Laval, and the Université du Québec à Montréal. Its mission is to promote and disseminate research.

https://www.erudit.org/en/ 


\title{
A Philosopher's Journey from Hermeneutics to Emancipatory Politics
}

\author{
DIETER MISGELD (with TREVOR NORRIS and HOSSEIN MESBAHIAN) ${ }^{1}$ \\ Ontario Institute for Studies in Education, University of Toronto
}

Professor Dieter Misgeld taught Philosophy of Education at the Ontario Institute for Studies in Education (OISE) at the University of Toronto for over thirty years. When we first arrived at OISE as graduate students, considerable mystique already surrounded Professor Misgeld. Many attested to his brilliance, range of knowledge, and at times intimidating personality. But there was also considerable curiosity about his intellectual shifts and what led him to turn away from philosophy. As described by the former chair of the philosophy program, "[F]or the first fifteen years when Dieter arrived in the philosophy of education group, he continually berated us for not being philosophical enough. For the last fifteen, he accused us all of being too philosophical."' We were intrigued by how someone who had received such an exceptional education from thinkers who have shaped much of 20th century thought could eventually turn away from philosophy and describe it as no longer useful. It is this transformation that we sought to understand.

Misgeld is an unconventional thinker: He was not the usual leftist or radical, yet not at all rightist. He was not a conventional secular thinker, yet not an anti-religious Marxist. He was not in any way a typical philosopher or writer, but had a role that would seem strange to many and difficult to explain to all. It soon became apparent to us that Misgeld defied easy categorization: he was political when he should have been philosophical, or historical when a political response would have been expected.

Because we have both been drawn to philosophy and sought to understand why Misgeld gradually turned away from it, our central motive and guiding question is: Why would someone educated in one of the most exciting intellectual environments of the 20th century slowly turn away from philosophy? We interviewed Misgeld in the fall of 2005, asking a total of seventy-five questions which we are preparing for publication as a book. In the following article, we explore three central factors that influenced this shift: his reading of Richard Rorty, his personal encounters with Buddhism, and his sometimes radical reflections on global politics and the new security regime, particularly in the context of Latin America.

The questions we asked Misgeld begin with his arrival in Canada and journey to take up his first university position in the icy and isolated northern mining town of Sudbury, Ontario, and then his career teaching philosophy of education at the University of Toronto. We then turn to his tumultuous

\footnotetext{
${ }^{1}$ Hossein Mesbahian is Professor of Philosophy at the University of Tehran. Trevor Norris is Assistant Professor of Philosophy in the Philosophy of Education program at the Ontario Institute for Studies in Education (OISE) at the University of Toronto (UT). They both studied under Dr. Misgeld, a professor of philosophy of education at OISE. This paper is drawn from interviews conducted with Dr. Misgeld in 2004 and 2005.

2 Dwight Boyd, personal correspondence, 2006.

(C) Copyright 2010. The authors, Dieter Misgeld, Trevor Norris, and Hossein Mesbablan assign to Paideusis the right of first publication and educational and non-profit institutions a non-exclusive license to use this document for personal use and in courses of instruction provided that the article is used in full and this copyright statement is reproduced. Any other usage is probibited without the express permission of the author.
} 
childhood during World War II, and then move to his years in Heidelberg where he studied ethics and hermeneutics with Hans Georg Gadamer, participated in debates about Hegel and Kant with Heidegger, and witnessed the beginning of Habermas' career. Thematically, we explore Gadamer's philosophical hermeneutics and Heidegger's politics, Habermas' account of modernity and modernization, and Misgeld's reflections on the limitations of postmodernism and the influence of Rorty. Educational issues include the influence of the Frankfurt School on the development of critical pedagogy, the role of the modern university in global politics, and shifts in education previously understood as self-formation (Bildung and Paideia), now couched in terms of students as 'clients'. We conclude with global political issues such as East/West relations, the fate of Canada in the world, and the importance of a Third World perspective and human rights.

Misgeld provides a dramatic account of his first arrival in Canada to take a position at Laurentian University in Sudbury, and the shock of this new country so far from the intellectual richness and picture-postcard beauty of Heidelberg:

I arrived in Montréal in 1968. I arrived by boat from Liverpool on the Empress of Canada, which was a boat which had carried many immigrants from the British Isles to Canada. The reason I went there was because I had a contract to teach in a college affiliated with Laurentian University in Sudbury. They were paying for the trip. It allowed me to transport our family goods, the furniture, and so on. After arriving in Montréal, I continued by an overnight bus to Sudbury in Northern Ontario. I remember that very early in the morning, past Ottawa I looked out the window, and all I saw was emptiness. There were very few towns. I was not used to that. Germany is very, very populated; every ten minutes, there is a village or a small town. There are no empty spaces. In Canada, there were rocks and very low trees, which I was not used to either, which made the landscape look even emptier. This is called the Canadian Shield, though I didn't know that was what it was called. That was really my first impression. This very empty landscape was something really completely new for me .... I was in place in a small university, the campus of which was outside of the town between two lakes. Heidelberg had been very different because the university was spread through the city; there wasn't just one campus location. I spent most of my time in the humanities and philosophy. We were in some of the oldest buildings, some from the 17th century. We were always down in the center of this old town. And here I was on this new campus. This Canadian university had been built just before I arrived, and had been built on top of rock. Sudbury is known for its huge nickel mines, especially Inco International, formerly a big US company, and tall smokestacks dominated the landscape, including the tallest smokestack in the world. There was smoke bellowing out and spreading throughout the area. Not only that, but in the process of nickel refining-of extracting nickel from the rock-chemicals had been used which also enter the air and did much damage to the area, as had open-pit mining and open-pit smelters in the past. The rocks look burned. I'd never seen anything like this_-black .... This was my experience of a place that was so far away as possible from anything I had ever encountered in Heidelberg. Philosophy or theory-especially my German traditions that I knew-seemed to matter very little.

Misgeld describes how the invitation to move from Heidelberg to Canada came about:

After completing my doctorate in Heidelberg with Hans-Georg Gadamer, I had begun a second program of studies in social psychology and phenomenological psychology, supported by a Volkswagen grant and on the recommendation of the Director of the Institute for Psychology with whom I had contact. I wanted to move into social science, after much classical philosophy. But very soon I got tired of having to study areas which really did not interest me, such as statistics and physiological psychology. I had expected to be able to move into my areas of interest more directly. An acquaintance from Quebec who had studied in Heidelberg and knew that I was fluent in English and had a reading knowledge of French, suggested that I come to Sudbury, the new Laurentian University where he taught and I could then see what I wanted to 
do next. I accepted, as did my then spouse, also realizing a strong desire for greater personal independence. In Sudbury I taught social and political philosophy, philosophy of culture, philosophy of the social sciences-also authors such as Kant, Heidegger, and so on. I also taught existentialism and phenomenology. My colleagues recommended that I teach these courses, second-year undergraduate courses, and then mostly third and fourth year, plus extension courses for extra income (we had debts). Thus, I taught twelve hours of formal teaching per week, as well as summers. Sometimes more.

What is in the background of this is that I had wanted to come to North America, primarily the US, having graduated from high school in Chicago as an exchange student. I had in fact applied to the New School for Social Research in order to study social science, but was told that this did not make sense, given that I already had a doctorate in a field not altogether different. But this also was the time of the Vietnam War, and it seemed important to me to maintain distance from the US, to develop a critical position, something which accompanies me to this day.

From this beginning in Sudbury, Misgeld moved to the University of Toronto. Although he was new to the field of philosophy of education and to a faculty of education, he gained familiarity with it while teaching about the Frankfurt School at OISE. At the time, the very active intellectual life at the University of Toronto included the famous literary theorist Northrop Frye, the media theorist Marshall McLuhan, political theorist Allan Bloom, political economist and critic of liberalism C.B. Macpherson, Canadian nationalist and political theorist George Grant, and even Misgeld's former teacher Gadamer who took a position for a few years at McMaster in the 1980s, and usually taught there for a few months in fall.

During my third year in Canada, and after an earlier visit to Frankfurt with Jürgen Habermas' team, I met Albrecht Wellmer, close associate of Habermas and important Frankfurt school philosopher in his own right. He was then going to OISE for a couple of years and suggested that I consider replacing him there, should he get an offer from New York (and later Berlin, which he did) and should I be accepted at OISE. I left Sudbury after having taught there for five years, also having been quite involved in faculty organizing activities (faculty association, university reform) and some politics (Canadian independence movement of the time). This then led to my planning to stay in Canada, given the attractiveness of the academic environment, and Toronto as a city of great diversity.

At OISE I taught a few courses similar to the ones taught in Sudbury, except that they were now geared toward education. But given my growing affiliation with Jürgen Habermas' project, or my interest in following it and reconstructing it, more and more elements of Frankfurt school thought became part of my work. This even included pragmatism and John Dewey, also as an alternative to the form of theorizing represented by the Frankfurt school, and building on Habermas' early remark that the two thinkers who had had the greatest influence on him in his youth had been Karl Marx and John Dewey. Thus, I taught "Democracy and Education" more and more frequently, always differently, focusing on Dewey, or Freire, or Buber, plus some Habermas, and later Rorty. I also taught "School and Society", which I used to learn more about standard philosophy of education. Later, after 1989 or so, human rights and human rights education, as well as theory, became an important interest. For I had then begun to work in Chile, a few years later in Mexico, often with groups in human rights and education. I had also begun to learn Spanish and to work with organisations in Toronto, such as The Canadian Centre for Victims of Torture. I joined the board of this organisation at some point and worked as a research director in a very applied project for them for a year. This work also led me to participate in activities of the Association of Moral Education [AME], publish a special issue of the Journal of Moral Education with Mary Brabeck, and I became president for a year of the AME. While at OISE, I also had the chance to teach the development of the Frankfurt School, its social philosophy, in the department of philosophy. I also taught hermeneutic philosophy and always brought my full-time OISE graduate students together with my $\mathrm{U}$ of $\mathrm{T}$ group. In 
this way, I was fortunate to consolidate an unusual approach to philosophy and philosophy of education in Toronto under more flexible conditions than I would have found in Germany.

Turning now to his childhood and education, Misgeld was born just as World War II erupted, which he describes as "the overwhelming presence and experience of my childhood." His father was held in a Russian prisoner of war camp for three years having been drafted into Hitler's army in 1939 and, as a result, he was raised primarily by his mother. The family fled their war-ruined town, becoming refugees within their own country, and struggling to survive for some time. Because of the tremendous social turmoil in Germany after the war, he says, "we children were raised like orphans in the wild."

The war proved very disruptive for Misgeld's education:

I didn't read much until I was eight. In fact, my mother said she was giving up. She thought I'd never learn to read. I didn't have dyslexia; I had no illness. I was intelligent enough to learn. If you ask me why, it is because there were other priorities. I was surviving in the countryside [and] in the street. I was part of the war. School was an artificial world. It closed after four months before I even knew what it was. The other important experience was looking for food I was looking for things to eat all the time. It was nothing different. Whether you went with a teacher, or on your own, you were always looking for something to eat. Thus, we spent the last week of school looking for berries in a forest.

Misgeld comments on the chaotic state of the German university after the war:

There was a lack of organization and structure and bureaucracy. On the one hand, there was an incredible openness, and on the other, it was a bit like the child in the war: you lacked many things but you were also extremely free because the adult world didn't function so they couldn't impose their rules on younger people as easily.

As a result, "much of my studying was done without teachers. It was continuing this wild education that I had had as a child because most of my exchanges were with friends."

Misgeld's interest in philosophy grew as the war years passed, motivated by a reaction against the situation in Germany at the time. His learning was quite self-directed:

I think I began to study philosophy out of rebelliousness .... In the last year of high school, I'd begun reading Heidegger and Christian existentialism, which led me to an interest in Protestant theology, having been brought up as a Catholic. I had no guidance. I had no teacher. I began studying Being in Time completely on my own ... I think something that did draw me to philosophy, maybe unconsciously at the time, was a certain pessimism. Something that does come through with Heidegger and his resistance to modernity is the sense of despair, that there may not be a good solution. There is a rejection of expectations of progress, of "a better world." This willingness to suffer through the disillusionment with various great projects of modernity drew me to philosophy, because one could not really be very hopeful about the future of human beings ... I was drawn to philosophy not because it would have explanations where other disciplines did not, but it would allow us to express our fundamental sense of things being out of joint, and without necessarily having a remedy.

And so he went in search of a teacher:

I decided to move from Bonn to Heidelberg because of Hans Georg Gadamer, because I discovered Truth and Method one day on the shelves in Bonn. The beautiful new university library, right on the Rhine, had a practice of displaying new acquisitions, and I came across Truth and Method. I looked at it and thought this was wonderful. I didn't know anything about Gadamer before I saw this book, and then I went to Heidelberg . . . . Before I met Gadamer, I really didn't have an academic teacher who was formative for me. He became formative for me 
because then I was looking for someone to guide me. I knew I needed someone. I wondered: where did Heidegger and this thought that I jumped into, like Being and Time and these existentialist themes, come from? I felt the need to have someone who really is, in the best sense, an academic teacher. In his older world, Gadamer had the same experience, as you see when you read his autobiography.

He also talks about the personal relationship that may develop between an academic and his student:

The personal relation was very important. If something changed, you could feel like an abandoned child. It was a bit of a father/son relation. Gadamer was a master at exploiting it, for being a very formative teacher. He was a very formative teacher, probably the most formative in German post-war philosophy. But it was hard to get away from that.

Misgeld contrasts that particular form of relationship with that prevalent in contemporary North American education:

I always stress that we, as academic teachers in North America, can never have the influence on students that someone like Gadamer had on me and many others. There is no one equal to Gadamer for me. With him, we grew into an older world. When Gadamer died, we lost a philosopher who was a living memory of our past.

However, problems began to emerge in the course of his dissertation. Gadamer insisted Misgeld work through more of the Western philosophical tradition before writing on Heidegger, beginning with Husserl's works. But Dieter was already becoming too interested in social theorists like Adorno and his critique of Heidegger, and through him, Habermas. At the same time that he was becoming interested in the newly-formed Frankfurt School, Gadamer asked him to co-teach a seminar on the pre-Socratics: "Concerning the dissertation, in some ways I stopped writing what I wanted to write because it became clear to me that I had to leave the context in which I had worked with Gadamer."

Adorno provoked a major shift for Misgeld:

When I began to read Adorno in the 1960s, the whole intellectual universe changed for me .... It was a direct attack on Heidegger and ontology and the talk about authenticity. I suddenly became aware that I had never learned to think sociologically. It was a bridge for me to the social sciences from philosophy and hermeneutic .... Adorno stood for the urbane, incredibly sophisticated, artistically, culturally advanced world of metropolis like Frankfurt and Berlin, very important during the years of the Weimar Republic and centres of resistance to Nazism, environments which Heidegger has always resented. Adorno was much more cosmopolitan, and could detect Heidegger's references to a peasant existence, which he says is archaic.

Misgeld described Gadamer as erudite but old-fashioned:

Gadamer always said he was not Heidegger, that he would never compare himself. I would say his work is rooted in a form of erudition which is very hard to have in our day, and hardly exists any more. For example, he could easily converse with people doing very highly concentrated and specialized studies in classical philosophy .... He was extremely erudite, learned in the old-fashioned, scholarly sense, and had a vast knowledge of different fields and different historical epochs. I think this is going to be hard to find. In some ways, it makes him inaccessible, because no one can put the Western tradition together like that, the way he did. But at the same time, he is sort of old fashioned. I think the world he understood ended with the Weimar Republic. Although he was quite astute in observations on politics, they were always very cautious, reserved, without deeper commitment to political intervention or convictions. He was quite capable of living in the modern world, but he was not a friend of it, 
sometimes even to the point that he said very amusing things—for example, that "privacy was lost with the invention of the telephone."

Gadamer had resisted many of the features of the modern world.

Although Misgeld is no longer as deeply interested in philosophy as previously, as a former student of Gadamer he is well versed in hermeneutics and philosophy. Misgeld stated in his contribution to a book on Gadamer that he "takes a strongly anti-utopian position, which includes the rejection of emancipatory politics as a real possibility of social transformation." 3 Therefore, his political position is thought to be deeply conservative. In his "Is Hermeneutics Necessarily Conservative?", ${ }_{4}$ Gary Madison responded critically to Misgeld, arguing that this is not a fair assessment. He acknowledges that, while Misgeld clearly shows that Gadamer takes a strongly anti-utopian position, he asks if Gadamer's anti-utopianism necessarily makes him a 'conservative'. Misgeld responds:

My difference with Madison already emerges when you look at the title of his essay. I would never use the phrase 'necessarily'. If he means to ask if hermeneutics is 'necessarily' conservative, no, it's not and nor is Gadamer's.

Misgeld adds that there is no correlation of necessity between anti-utopianism and the rejection of emancipatory politics, insofar as the latter can be a search for a real possibility of social transformation. Misgeld asserts that he neither argued that hermeneutics was necessarily conservative, nor that Gadamer's anti-utopianism necessarily made him a conservative:

What I was arguing there was that Gadamer's understanding of politics is deeply conservative in the sense that he has tremendous doubts about our capacity to change and a major change such as has happened in the formation of European modernity can be extremely risky. To him, large scale change is best not aimed at or planned, because it can rarely, if ever, be achieved. More than anything, comprehensive planning is the problem for Gadamer.

In spite of this, it does not at all follow that Misgeld lacks admiration for Gadamer. He suggests there is no necessary antagonistic relationship between admiration for a mentor and a critical attitude towards some aspects of his thought. Misgeld remembered Gadamer as the professor whose door was always open to students, as the one who joined them in many discussions, and made philosophy an unforgettable experience.

One of the notable features of studying with Gadamer was that Heidegger was occasionally present for seminars and social outings. Gadamer would host weekly discussion groups in his home which Heidegger would occasionally attend:

There were occasions when Heidegger came and gave lectures, and we would have private seminars with him and then go out and drink wine. He would get quite annoyed with us in the seminars. He said "You're trying to translate me back into Hegel. I'm not a Hegelian. In fact, that's what I'm trying to escape." But there were a couple of pretty belligerent and capable people who were always trying to do that .... Heidegger, who was a little man, would go from table to table. He was incredibly quiet. As forceful as he was in public as a speaker, he was extremely discreet and quiet with us .... I don't remember him saying much, commenting much on what he heard around the table, in a café or nice little old restaurants in country inns

\footnotetext{
${ }^{3}$ Dieter Misgeld. "Poetry, Dialogue and Negotiation: Liberal Culture and Conservative Politics in Hans-Georg Gadamer's Thought.” Ed. K. Wright. Festival of Interpretations: Essays on Hans-Georg Gadamer's Work. Albany: SUNY Press, 1990. 170.

${ }^{4}$ G.B. Madison. "Is Hermeneutics Necessarily Conservative?” University of Alberta. n.d. Web. 21 July 2005.

$<\underline{\text { http://www.ualberta.ca/ } \sim \mathrm{di} / \mathrm{csh} / \mathrm{csh} 10 / \text { Madison.html }>}$
} 
where we'd go and drink regional wine. This was not the Heidegger whom one had heard about, the Heidegger of 1933 who had become rector of his university, the University of Freiburg in Baden. That other, younger Heidegger was very ambitious, and wanted to be the national philosopher under Hitler . . . . He became quite ruthless for a couple of years. There are letters which did much harm to people, which led to their being fired. As a rector, he was ruthless. My guess is that it took from about 1933 to about 1938 before he woke up a little.

Misgeld suggests that Heidegger's support for national-socialism was due to his beliefs about metaphysics and technology, combined with his naive and romantic nationalism.

Heidegger was a real National Socialist. That is my reading of Heidegger. What does that mean? A National Socialist is someone who believes that the socialist system benefits national sovereignty. Germany was to wake up as a nation, to assume its destiny as a collectivity. This would be the meaning of socialism - as the collective project of Germany as a nation to be rebuilt. For Heidegger, Germany was worth defending its history, its language, its culture. But it could not be defended and would not survive as a liberal democracy. He was not alone in that. Parts of the Left thought this as well, but his was coming from something that I think only existed in Germany, National Socialism, which the Nazis then transformed into what we always hear as just racism. But there were different forms of it. There was a form which was a kind of socialism rooted in German ethnic identity or national history and language, and was an alternative to Bolshevism on the one hand, probably even before they knew how Stalin had distorted and perverted the Communist International. On the other hand, commercial cosmopolitanism, which many Germans such as Nietzsche saw coming from the Western liberal democracies, they perceived as rooted in commercial empires. That's not so wrong when you read history backward from the United States to Britain. Germany for them was a country in the middle. Even later, Heidegger would say this, that it was neither east nor west, neither liberal nor commercial democracy. To many Germans critical of the West at the time, the two went together. Liberal democracy would also be commercial, another phrase for capitalist—not that this realization would lead them toward Marx and his critique of capitalism. But for them, it meant that what Nietzsche would call the mentality of the merchant would prevail, on the one hand, and on the other what they saw as the collectivist proletarian internationalism of the Soviet Union. Germany was caught between the two . . . . Heidegger had a commitment to Germany as a nation, as something that had been hurt and violated by the defeat of the First World War and the Versailles Treaty. He was someone who could never align himself with Marxism, but even more so he had no comprehension of it, only disdain and fear of it.

Misgeld describes Heidegger' retreat from national socialism: "It's clear when you look at some of the lectures from 1936 on that there are certain clear reservations expressed that were against Nazi ideology on race," which he says is, "a degenerate metaphysical category." Yet, Misgeld certainly remains deeply critical of Heidegger:

I actually think, and I can feel it in the writing, that there had been much suffering on Heidegger's part, but that he felt that he had to deal with this himself. But that is coupled with this megalomaniacal streak, with this tendency to think that these are things only he can and only he has to answer in his work. That he felt that in his work as a thinker it would be addressed in the deepest possible way and so he didn't have to give an explanation. What comes through is that he was not a very dialogical thinker. He was not attuned to communication with others. The social dimension is like an externality to him.

It was the lack of consideration for a 'social dimension' that led Misgeld to Habermas, who he helped popularize in Canada and North America. Although Misgeld was never a student of Habermas, and his connection with him was formed primarily when he was already teaching in Canada, he has 
written numerous essays on several aspects of Habermas' thought, both critically and admiringly. ${ }^{5}$ Promoting Habermas was initiated by Gadamer: "Without Gadamer, Habermas would not have had the career that he has. It was Gadamer who recognized him very early on when one or the other among Habermas' teachers in Frankfurt had problems supporting his career." Later on, Misgeld was among those who expressed the view that Habermas should be discouraged from accepting any of the numerous offers from prestigious American universities which he had received.

I believed that he should not to leave Germany, not leave Europe. He would become one among many, as his translator, Thomas McCarthy, had mentioned to me. He'll just be another academic; he won't be a John Rawls. Habermas would never reach their stature because his way of thinking is too alien, too technical, too complex, too unclear because he tries to put together so many considerations. Why does he do that? Because he wants to combine so many different traditions. In the States, that doesn't wash, as Americans say.

Misgeld would often return to Germany in the summer to follow intellectual developments and meet with the Frankfurt critical theory group as well as Habermas himself.

I'd finish teaching in Toronto and then right away go to Frankfurt, because the summer semester there was in process, and would go from April until July. I could be there for several months. You couldn't come there and not give a paper. Jürgen Habermas would say, "What are you going to present? What are you doing now?" You could hardly come into his room and not get into very intensive discussions. I remember once coming to Starnberg at his Institute, ${ }^{6}$ and he involved me right away in this whole "speech theory" business, communicative action, types of speech action, before I entered the door. I really couldn't follow . . . . but I could just see what he was working on. That's just how intense he is.

Yet Misgeld is deeply critical of Habermas' theory of modernity. He regards it as too impractical.

The problem with the concept of modernity is that it is not forceful enough as a critical contrast to modernization ideologies that come from the international financial institutions and powerful governments. In The Philosophical Discourse of Modernity, Habermas distinguishes modernity and modernization-and then he escapes into philosophy. That is a real cop-out, because the issue is very real. Modernization theories cost lives. They destroy peasant societies without giving a significant alternative. They feed into models that are ecologically extremely harmful. They feed into the whole mega-project way of thinking .... So you only have two options: either a highly exploitative system where some people will have golf courses and swimming pools, which use enormous amounts of water, or as I've seen in Latin America, not every household would have water and people would have to walk hours to get water or they get it every second or third day. Massive inequalities: that's the future. There is no other. No modernization theory or theory of modernity I've seen is realistic enough, tough-minded enough, and fearless enough to face these situations. Philosophers are generally not capable of facing realities ... Only those who share Habermas' philosophical dreams think "modernity" is

\footnotetext{
${ }^{5}$ Misgeld, Dieter. "Critical Theory and Hermeneutics: The Debate Between Gadamer and Habermas." Ed. J. O'Neil. On Critical Theory. NY: Seabury Press, 1976. 164-184; Misgeld, Dieter. "Critical Hermeneutics Versus Neoparsonianism? A Critique of Habermas' Theory of Communicative Action." New German Critique 35 (Spring/Summer 1985): 55-83; Misgeld, Dieter. "Justifications and Application." Rev. of Justifications and Application: Remarks on Discourse Ethics. Trans. Ciaran P. Cronin. The Review of Metaphysics 48 (1995): 657-658; Misgeld, Dieter. "Knowledge of Human Interests." Dialogue 11.4 (1972): 639-643; Misgeld, Dieter. "Toward a Rational Society," Dialogue 11.1 (1972): 155-159.

${ }^{6}$ Habermas was a director (one of two) at the Max Planck Institut fuer Erforschung der Lebensbedingungen der technischwissenschaftlichen Welt at Starnberg, Bavaria, FRG.
} 
a concept that describes reality. The problem with so many global or comprehensive philosophical concepts is that they have no purchase on reality.

Misgeld easily moves from critical views on Habermas to larger questions about philosophy itself:

I don't want to work on developing "a theory" of anything anymore. I want to work on realities, realities of human beings. Sometimes some theorizing is useful, but I wouldn't privilege it, let's put it that way .... In many ways, I think concepts never really give us the whole reality of who we are as human beings, and so it's important not to get stuck on them ... Philosophy leaves everything as it is. That certainly used to be a tendency in analytic philosophy. They would ask: why do you want philosophy to have an impact? It has nothing to do with that-it's a second-order inquiry. You can say that analytic philosophy is fairly honest, and it downplays the importance of philosophy. But then why would anyone want to stay with philosophy if its human impact is so marginal—unless they like intellectual games .... When I look for remedies for the problems, I don't look for foundations. I would look for ways of life that are sustainable for people which are not harmful.

Much of Misgeld's critical attitude towards philosophy emerges from his readings of philosopher Richard Rorty:

I think I agree with Rorty, and the post-moderns, and in the end with Heidegger, that as a foundational discipline, philosophy is no longer viable .... The philosophers we have talked about represent, as Habermas honestly once said, 'Old Europe' . . . . Rorty made me think more about theorizing and its limits ... . The Frankfurt School had no sense of limit. They tried to theorize the impossible, the non-theoretical and the non-utopian, while at the same time maintaining and reinforcing utopian anticipations of a society beyond what we know society to be.

These critical attitudes were deepened through his meditative practices and engagement with Zen Buddhism:

There's absolutely nothing in Western philosophy that would prepare me for the radical rejection of concepts as something that matters, as in Zen Buddhism. It's better not to look for concepts and conceptual explications.

Misgeld finds a link between Zen Buddhism and Heidegger:

Heidegger gave evocative descriptions of experiences which require a different environmentthat one's relation to things is not functional but rather a lived relation of association and connecting, even with things. I learned to appreciate this through Zen Buddhist practice, where there is much emphasis on, for example, bare surfaces, where you always prefer less rather than more. Heidegger has much of that sparseness.

These reflections on Zen Buddhism led him to reconsider notions of home and homelessness in the context of his changing political identity having moved from Germany to Canada to Latin America, and from German to English to Spanish. When asked "Do you ever feel 'Canadian'? Where do you feel at home? Do you feel that such a thing is necessary or possible?", Misgeld replied, "I would like to feel at home, but I actually don't feel at home anywhere." In response to his experience of homelessness as he has moved from a German youth and education to career teaching in Canada to Latin American politics, Misgeld claims that 
There's only one place where one can be at home, and that's the place one has to leave. We all have to die. Homelessness is the human condition. I've learned that from Zen. We are not made to be at home permanently. The only thing permanent is impermanence. From that point of view, I don't think it is good to be too deeply attached.

This changing political identity and diverse political experiences combined with his extensive teaching and writing about human rights, dialogue among cultures, and the Third World perspective leads him to a deep concern about the hazardous situation of the world in our day:

\begin{abstract}
Whenever I think of the global situation, I get quite anxious .... We may face something quite vicious for some time. When I think about our times, I don't think anyone really knows what the future holds. I think in some ways Heidegger's pessimistic vision is plausible. I think we will encounter several major political catastrophes .... I am hopeful with respect to some parts of the world, but not with respect to the so-called developed industrial societies. I think they are the ones that are most endangered, and they are the world-wide danger.
\end{abstract}

Misgeld referred to various aspects of globalization which are profoundly harmful, ranging from the neglect of the interests of poorer nations and marginalized populations, a corporatist agenda intent on constricting the freedoms of individuals in the name of profit, the flow of savings into the United States rather than developing nations, and the imperialistic aspects of globalization. Misgeld also referred to the broad anti-globalization movement which includes national liberation factions, left-wing parties, environmentalists, anti-racism groups, and libertarian socialists. While reformist groups are arguing for a more humane form of capitalism, Misgeld argues for a more humane system than capitalism. While many, such as Noam Chomsky, have decried the lack of unity and direction in the anti-globalization movement, Misgeld believes that this lack of centralization may, in fact, be a strength.

Given our interest in philosophy, we found Misgeld's characterization of its lack of relevance particularly provocative. Despite his profound knowledge and background, he argues that philosophy is no longer helpful for responding to or shaping social and political change because the problems of the world today are of political rather than philosophical importance. The world is in a political rather than philosophical crisis, so it is politics rather than philosophy that is required:

I've become more sceptical about both theories that explain and philosophy as expressing how things are out of joint. Perhaps sceptical is not the word. I look for other remedies. I don't find them sufficiently strong as remedies.

Remarkably, he asserts that he has come to this conclusion via philosophy itself. Considering the stature of his teachers and the depth of his own philosophical capabilities, his insistence on the limitations of philosophy compels us to reflect on our own assumptions about the promise of philosophy.

With Dieter Misgeld, we see the seductions of philosophy when studied among this century's greatest practitioners. We also see the reversal of conventional life narratives, which as Robert Frost claims, often begin radical and slowly turn conservative (although we do not claim this of Misgeld): "I never dared to be radical when young for fear it would make me conservative when old." 7

Ironically, we as authors and interviewers have been motivated by things Misgeld is no longer interested in. When asked if he felt fortunate to have had the opportunity to study with and known some of the greatest thinkers of the $20^{\text {th }}$ century (Gadamer, Lowith, Adorno, Heidegger, and Habermas) in such an extraordinarily dynamic intellectual environment, Misgeld responded:

${ }^{7}$ Robert Frost. "Ten Mills.” A Further Range. London: Cape, 1936. 
I can't even see who I would be without having had that experience. I certainly feel that I am indebted to them. Fortunate is probably not the word. If I hadn't had that experience, nothing else would have touched me as it has .... I I could very well see ways of life that I might have chosen which would have never led to any attachment with philosophers, or theorists or philosophy, as equally good to what has happened to me, or with me, where I would have possibly been happier. I'm not sure that being part of great intellectual projects is always conducive to happiness or well-being. Sometimes simpler ways of living are preferable, but I think it would take us a long time to understand that in our culture.

What we find in Misgeld is of interest not only because of his philosophical background or remarkable transformations, but because he provokes us to understand and re-examine our own motives for philosophical reflection and to recognize the limits of philosophy. What emerges from this biographical study is both a philosophical profile of the second half of the twentieth century and a portrait of a pedagogy of hope based on Misgeld's own utopian aspirations, emancipatory politics, and wariness toward philosophy. In sum, it is not only an intellectual biography or an account of particular political positions and philosophical reflections, but a compelling life story.

In a dramatic statement, Misgeld communicates his emancipatory political project: "I already know what I ideally want; that's fairly easy - the universal emancipation of humanity from bondage and suffering where possible." His emancipatory politics became more apparent to us when Misgeld was asked to accept the invitation from the Iranian "International Centre for Dialogue Among Civilizations." "The first question he asked was if it was useful for Iranian people in their political struggle. He didn't consider the invitation to be an opportunity to go abroad and participate in an adventure. This position was also clearly articulated in his comments on an academic visit to Iran, published in TPS Quarterly under the title "Zarathustra's Land Beyond Good and Evil". He says there that "[h]esitating initially due to my doubts about the Islamic Revolution in Iran in 1979 (and knowing that it had been extremely brutal in its aftermath), I accepted the invitation after President Bush's speech mentioning Iran as belonging to the "Axis of Evil"'. ${ }^{9}$ This revealed something significant to us about his own political inclinations. In his view, it was important not to accept this demonization of a country with a very rich and ancient history. Most exceptional philosophers such as Michel Foucault and Jürgen Habermas have lectured in Iran for similar reasons, believing that communication has to be maintained and opened up.

Misgeld's talk at the Iranian conference addressed the hegemonic role of the United States, with reference to elements of pragmatism as its philosophical tradition, contrasting it with a Latin American vision of the Americas. Some of this work, first published in Mexico, is now being continued, especially an exchange with Argentinean friends and colleagues. The focus is on Latin American humanism (Freire, liberation theology) as an alternative to 'American' technological humanism (pragmatism). Practical commitments and work in oppositional and human rights organisations at the community level are part of this project.

We end by expressing our gratitude to our unconventional teacher, Dieter Misgeld. He encouraged us to be ourselves, to trust intuition above all else, and to find our own individual paths. He

\footnotetext{
${ }^{8}$ In response to the proposal made by the president of the Islamic Republic of Iran, the United Nations' General Assembly declared 2001 as the year of Dialogue Among Civilizations. The Iranian government subsequently founded the International Centre for Dialogue among Civilizations (ICDAC) in February 1999. ICDAC is primarily an organization intended to promote the concept of a global structure based on mutual understanding and tolerance. For more information about the center see its official website: http://www.dialoguecentre.org, (Accessed July 21, 2005). Misgeld participated in an international seminar on "Centre and Periphery" organized by ICDAC's Department of Philosophy May 1-2, 2002, in Isfahan, Iran. Twenty one lectures (eight by Iranian thinkers) were delivered during the two-day event. Participants came from a variety of countries including the U.S., and speakers included Fred Dallmayr, Mahmood Dolatabadi, and Daryoosh Shayegan.

9 Dieter Misgeld, “Zarathustra's Land Beyond Good and Evil,” TPS Quarterly 3, no. IV (July 2002): 3.
} 
is a teacher of hope, vision, and creativity, who seeks to teach through paradox. Sometimes it seems he may have sent us in the wrong direction or presented an odd perspective so as to provoke consideration of our philosophical assumptions. He would avoid providing answers, but compelled independent thought. It was inspirational to witness such an unconventional figure teach something for which he had such passion. Beyond his significant impact on the development of our own intellectual orientations, his perspective on the world's philosophical and political issues presents an exciting and new cross-cultural perspective that should be broadly engaged. While Misgeld's life narrative is certainly unconventional, it raises questions that may be of interest to the larger academic community.

Misgeld says that with Gadamer, "we grew into an older world." Yet with Misgeld, just as we grow into the world of philosophy, we are cast off into the turmoil and troubles of the present global political system. Yet through these shifts, Misgeld's thought resonates with truth, wisdom, and inspiration, offering a refreshing perspective on human life and values.

\section{Works That Have Significantly Influenced My Thinking}

\section{Prior to university and first years of university:}

Buber, Martin. Ich und Du. Heidelberg: L. Schneider, 1977. [I and Thou. New York: Scribner, 1958.]

Camus, Albert. La Peste. Paris: Gallimard, 1947. [The Plague. London: Penguin Books, 1960.]

Heidigger, Martin. Sein und Zeit. Tübingen: M. Niemeyer, 1960. [Being and Time. New York: Harper \& Row, 1962.]

Sartre, Jean-Paul. La Nausee. London; Wolfeboro, NH: 1987. [Nausea. Norfolk, CT: New Directions, 1949.]

More advanced student years and beyond:

Adorno, Theodore W. Negative Dialektik. Frankfurt: Suhrkamp, 1977. [Negative Dialectics. New York: Seabury Press, 1973.]

Gadamer, Hans G. Wabrheit und Methode. New Haven: Yale University Press, 1985. [Truth and Method. New York: Seabury Press, 1975.]

Habermas, Jürgen. Erkenntnis und Interesse. Boston: Beacon Press, 1972. [Knowledge and Human Interests. Boston: Beacon Press, 1972.]

Heidegger, Martin. Vortraege und Aufsaetze. Pfullingen: G. Neske, 1959. [The Question Concerning Technology and Other Essays. New York: Garland Publishing, 1977.]

\section{Career:}

Dewey, John. Democracy and Education. New York: The Macmillan Company, 1936.

Freire, Paulo. Pedagogy of the Oppressed. New York: Continuum, 1989.

Galeano, Eduardo. Open Veins of Latin America: Five Centuries of the Pillage of a Continent. New York: Monthly Review Press, 1973.

Gutierrez, Gustavo. En busca de los pobres de Jesucristo: El pensamiento de Bartolomé de las Casas. Salamanca: Sigueme, 1993. [Las Casas: In Search of the Poor of Jesus Christ. Maryknoll, NY: Orbis Books, 1993.]

Habermas, Jürgen. The Theory of Communicative Action. Volumes 1 and 2. Boston: Beacon Press, 1987. Marcuse, Herbert. Eros and Civilization: A Philosophical Inquiry into Freud. Boston: Beacon Press, 1955.

Rorty, Richard. Achieving our Country: Leftist Thought in Twentieth-century America. Cambridge, MA: Harvard University Press, 1998. 